\section{LEGAL NOTICE}

Thl report was peepared as an account of work eponsored by the United Statet Government. Noither the United States nor the United States Atomic Enersy Comminaton, nor any of theze employees, nor eny of their contractors, cubcontractors, or their employees, makes any warkenty, exprese or implied, or amumas any makes any marnenty, exprowity for the eceurscy, com-

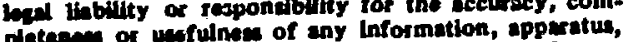
pietenas of weces dincloend, or reprosents that lit ues weuld wot infelinge privatoly owned rights.

$$
\begin{gathered}
\text { SM- } 1: 81 \quad 10 \\
\text { CONF-700810--28 } \\
\text { MASTER }
\end{gathered}
$$

\title{
CRITERIA FOR THE CONTROL OF RADIOACTIVE EFFLUENTS*
}

\author{
By \\ K.Z. Moroon and E. G. Struxness \\ Health Physics Division \\ Oak Ridoe National Laboratory \\ Ook Ridge, Tennessee
}

\begin{abstract}
Some uniformity in regulating radioactive effluents from reactor power plants is highly desirable. Several approaches have evolved which fall short of providing information needed for realistic assessments of effluent hazard and the application of radiation protection guidelines oftentimes is superficial or mistaken. Failure to move foward uniformity in this area endangers both optimum development of nuclear energy and protection of the public health.
\end{abstract}

Frequently, three mistakes are mode in this connection: (1) the rules and regulations fail to relate a given plant discharge rate to some potential population dose; (2) the dose criteria used for measuring "safety" do not make proper allowance for potential population doses from other sources; and (3) the planners or regulators, in the one extreme, overlook conservative approaches to keeping all doses as low as practicable or, in the other extreme, set an unreasonable price for radiation safaty by demanding that all doses be kept as low as possible. 
It is sugested that a suitable basis for uniformity in be found in criteria based on recent recommendations of ICRP. The ICRP emphosizes that the anruval dose to individuals and the genetically significant dose to whole populations are the important criteria for detormining whother given operations are wafe from the standpoint of rediation exposure. It de-emphosizes the desirability of placing reliance on wecondary standards, wch as the concentration of radionuclides in air and water at the boundary of a piant. Additionally, the ICRP's concept of "critical" rodionuclides, pathways and population groups provides a practical mechanisan for simplifying complicated assasuments, taking account of the known or expected behavior of released radionuclides in the plant environs and their interactions with populations likely to be affected. Considering potential expoures and estimating dows in this context, it is then appropriate to compare the estimated dose(s) to critical group(s) with ICRP's population dose limits in deciding whether the release is "sofo".

Factors are discused that have a significant bearing on efficacy of the assosement, including: (1) description of released radioactive material; (2) environmental pothways;

(3) bioenvironmental behavior of released rodionuclides;

(4) population distribution, habits and characteristics;

(5) radiation dosimotry applications; (6) primary standards;

(7) dose apportionment; and (8) dose criteria for reactor effluents.

Introduction

At the outest of thes discussions, we would like to make it clear that although we are employees of Oak Ridge National Laboratory, members of the Health Physics Society and the International Radiation Protection Association, and closely associated with the work of the International Commission on Radiological Protection and the National Council on Radiation Protection, the opinions we express here cre cur own and do not necescorily represent the viows of these organizations.

In discussing criteria for the control of redicactive effluents from reactors and associated facilitios, it must bo kept in mind that overything, including effluents from all power plants whether they oparate with fowil fuels or nuclear energy, contains some radioactive material. Therefore, we will not consider how 
these levels of radicactive contamination in effluents from reactors and their facilities can be reduced to zero or even to the lowest possible level but how the total contribution to the environment can be kept at a practical and reasonably safe level. Most of our discussions will deal with the matter of routine discharges of radioactive waste to the environment, but we will not overlook the possibility of rare events which might permit the accidental release of large quantities of radioactive material. In this latter case, we. would like to make it clear at the outset that we will not consider a nuclear explosion of the type that occurs with the detonation of a nuclear weapon because such explosions with nuclear power plents and their facilities are impossible. In the case of routine discharges of radioactive wastes, we will be concerned at most with the release of a few curles per day resulting in a faw microcuries/ce of air or water in the immediate environment of these facilities, and in the rare event of a major accidental release, we might be concerned with the rather sudden and short-period release of a percent or $s 0$ of the fission inventory amounting to many gigacuries to the environment. Protection from occurrence of the latter type of release is provided by many safety features built into the reactor system and incorporated in operating procedures, in the several containment systems and in the isoletion provided by the low population zone surrounding the facility and usually a considerable distance to the nearest population center. These features of the reactor system should be such that the probability of a major accidental release is exceedingly small (not greater then $10^{-4}$ and preferably as small as $10^{-5}$ accidents per year per reactor). If the probability of such an accident approaches a negligible value, we believe the principal thrust of this paper should be directed toward routine discharges of radioactive contamization. A study by. Martin et al $(1)$ has shown that the sadioactive gases discharged from a boiling water reactor can produce more radiation exposure to man than the natural radicactivity from an oldar, less efficient-type of coal-burning power plant bot that this cool plont can produce more sir-borne madiation exposure than the gases from a presurized water reactor. The air contamination by nuclear plants is predominantly from 
redlocetlve noble gaws ( ${ }^{85} \mathrm{Kr}$ mout digniffeant) whilch do not concentrate in the body and are responable primarily for external expowe. In sharp contrest,

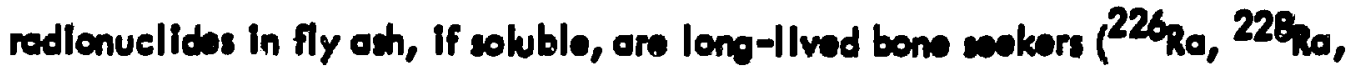
${ }^{232}$ Th, ${ }^{228}$ Th and 200 Th) and a kidney sacker (238 U) that may roside in body organs for a vary lang tims. It follows, therefore, that for some types of power ptants the rodiation rick to persens llving downwind may be greater from fosil fuel plants than from those oporating on nuclear fual. In addition as indicated by Table 1, (2) fosil fuel plants contribute about $25 \%$ of the nitrogen oxidas and particulate matter and about half of the oxldes of sulphur as nrajor pollutants of our atmouphore. Therefore, in considering the accoptability of certain ricks introduced by nucleor power plants, we must not overlook the desirability of choouing the bever of the evils to man and his environment when meating the future needs for electricol power. In addition to gaseous discharges of rodioactive material from a nucleor powar plant, there will be low lovels of radionuclides in the cooling water, a small fraction of which reaches water in the hursan environment. This consists of a fraction of a mierocurio/ec of water of mixed fiesion products wch as ${ }^{3} \mathrm{H},{ }^{90} \mathrm{Sr},{ }^{137} \mathrm{C}_{3,}$ ate., and induced radionuclides wch os ${ }^{3} \mathrm{H}, 24 \mathrm{Na},{ }^{32} \mathrm{P},{ }^{60} \mathrm{Co}$, etc. As will be emphasized if the following discusions, often the principal radiation riak to population in the.noighborhood of these nuclear power plants is not from direct external exposure to the redicactive cleud or the internal exposure from drinking the radioactive water from the rivers below the plants but rather from the buildup or reconeentration of these radionuclides in certain parts of men's food chain.

In providing adequate radiation protection for members of the public, the concentration of radioactive materials in the air, water and food as a consequence of reactor operations must be kept at wch a low lovel that the risks of somatic and genotic injury are excoedingly low and loss than or comparable with those introduced by other common industries and they must be acceptable by the individual and the society of which he is a part. During the past fow decodies, there have been procressive (or perhaps ragressive) ehanges in terminology und for wetting acceptable levels of exposure, ise., from tolerable 
Table 1

SOURCE OF AIR POLLUTION (2)

(in millions of tons annually (1966))

\begin{tabular}{|c|c|c|c|c|c|c|}
\hline & $\begin{array}{l}\text { Corbon } \\
\text { Monoxide }\end{array}$ & $\begin{array}{l}\text { Sulfor } \\
\text { Oxides }\end{array}$ & $\begin{array}{l}\text { Nitroson } \\
\text { Oxides }\end{array}$ & $\begin{array}{l}\text { Hyctro- } \\
\text { Corbons }\end{array}$ & $\begin{array}{l}\text { Porficulof } \\
\text { Matter }\end{array}$ & Total \\
\hline Motor vehicles & 66 & 1 & 6 & 12 & $\mathbf{1}$ & 86 \\
\hline Industry & 2 & 9 & 2 & 4 & 6 & $\mathbf{2 3}$ \\
\hline Power plants & 1 & 12 & 3 & 1 & 3 & 20 \\
\hline Space heating & 2 & 3 & 1 & 1 & 1 & 8 \\
\hline Refuse disposal & $\mathbf{I}$ & 1 & 1 & $\mathbf{1}$ & 1 & 5 \\
\hline Total & 72 & 26 & 13 & 19 & 12 & 142 \\
\hline
\end{tabular}


to allowable to permisible to working lovel, etc. Some of these changes were introduced to get away from the concept that there is a level of exposure or a threchold dow which is tolorable and which would not produce any body damage. Some persons have not liked the use of the word "permissible" because it seems to suogest that this amount of expoure is quite accoptable and would not warrant measures to reduce expossres below this lovel. The expression of maximum permissible exposure" has led to some diffieulties because on occasion it has sugosted that below this lovel one is sofe, but at slightly above this level the person may suffer sorious coneaquences. Although prior is about 1930 many persons thought there was a threchold dow of lonizing rediation below which there was little or no radiation damage, more and more information has accumulated since then to stow that although there seems to be some repair of radiation damage in time, a certain fraction of the radiation damage is permanent and cumulafive. Until man has developad a completely coherent theory of radiation damage, it may not be poselble to state precisaly the risk involved to a human population exposed to very low doses at very low dose rates. In animal studies as the doses under investigation. become smaller, the number of animals required to prove the existence of an effect soon becomes prohibitivaly large. In humon studies, there ore many obvious difficulties in obtaining direct information on the effect of doses of levels considerud acceptable as maximum permissible values. However, there has been a number of epidemiological studies by Brion MacMahon and others ${ }^{(3)}$. of the affects of low diagnostic exposures, e.a., 1 to 3 rads to woman during pregnancy. Some of these studies have involved hundteds of thousands of children and indicate an increased incidence of leukemia of 30-10\% among the children of these mothers compored to childten not 80 exposed in uterol. Genetic studies of Rusell ${ }^{(4)}$ indicate that for mice at decreasing dose rates, the number of point mutations per roentesn following exposure to occytes of the female begins to drop off at about $5,000 \mathrm{R} / \mathrm{hr}$, and the drop continues on presumably to the backeround level at dose rates below about $0.5 \mathrm{R} / \mathrm{hr}$. However, for expoure of the spermatogonia of moles, the drop-off in point mutations per reentgen begins at the some dose rate of 
about $5,000 \mathrm{R} / \mathrm{hr}$ but having dropped by a factor of 3 reaches another plateou at about $50 \mathrm{R} / \mathrm{hr}$ and continues on this plateau with no further reduction in mutations per roentgan on down to doses as low as $60 \mathrm{mR} / \mathrm{hr}$. Thus, the number of genotic mutations per roentgen for mice exposed at very low dose rates wich as are commonly encountered at permissiblo lovels appecrs to be reduced no more then by a factor of six bolow what is obsarved at high dow rates. With such data in mind, the only prudont asumption that can be made by agencios which sot radiation standerds (the National Council on Rodiation Protection and Moasurements, NCRP, and the Federal Rediation Council, FRC, in the United States and the International Commission on Radiological Protection, ICRP, on the international leval) is and has been that there is no thresthold dose or does rate so low that the probability of radiation damage is zero, and thers is a hways some riks of rodiation damege even at very low dows and dowe rates such as thowe recommended as accepplable for population expowure. Table 2 summarizes the basic asumptions made by ICRP $(5)$ in satting radiation protaction standards and values of permisible dose. It hes been the practice of ICRP, NCRP and FRC to st the permisible expowere values for members of the public at $10 \%$ of those allowed for the occupational workers. The reasons exposure levels for members of the public are set lower than those for the oceupational workers are summorized in Table $3 .{ }^{(6)}$

From the above discussion, it is realized that parmissible exposure lovels to lonizing radiation for the occupational workers or members of the public are not set on the thessis that below thes levels there will be no risk oven of the more serious forms of radiation damage such as loukemia, thyroid cuncer, bone tumors or mental defects and doformitios to the offapring. However, they are set wuch that the risk is exceedingly low and, hopefully, sufficiently low to be worthy of accoptance by society in view of the benefits that are expected, in this case from the nuclear energy industry. The hypothesis used in sefting thes levcis is that the rick is independent of does rate and increases linearly with aceumulated dose and the number of individuals exposed. Thus, the population risk can be doubled oither by doubling the overage cecumulated dose or doubling the size of the expoesed population; it would be increased by a factor of 4 by doubling both. 
Table 2

MSIC ASSUMPTIONS MADE BY ICRP IN SETTING RADIATION PROTECTION STANDARDS AND VALUES OF PERMISSIBLE DOSE

1. They corry a negligible probability of avere somatic a enotic injurios.

2. Effects that enave more frequently, - .0., life hortening, ore of a minor noture and are accoptable to exposed individuals and by compatent madical cuthoritios. These offects are hidden by normal biological veriations.

3. Severe somatic injuries, to., leukemic, are limited to an exceadingly smoll frection of exposed group. 
Table 3

\section{REASONS WHY RADIATION EXPOSURES OF THE POPULATION AT LARGE MUST BE LESS THAN THOSE PERMITTED TO THE OCCUPATIONAL (6) (28) WORKER}

1. These other groups are lerger, hence contain a correspondingly larger number of individuals with injurious effects per rem of dose equivalent.

2. Employment involving occupational hazard from radiation exposure is voluntary and, in principle, the hazard can be foreseen by the individual accepting the risk that may be involved.

3. Industrial workers are screened so those least able to meet any particular hazard may be channeled into other activities.

4. In industry there can be evaluation and control of the hazards by radiation monitoring.

5. Population groups other than occupational are more likely to confuin children and embryos that are more sensitive to radiation domage and also they may contain older adults who may be more susceptible to radiation damago.

6. The number of years of occupational exposure will be less than the number of years of envisonmental exposure.

7. Each indusiry cannot be permitted to impose a full measure of its peculiar occupational hazards on the environment. 
Although at first it seems to surprixe some people when they realize there is apparently no so-called safe level or threshold of exposure to ionizing radiation, this is by no meanz an unusual situation. For example, statistically, we can set the risk on a mile basis for travel by commercial airlines. Making some simplifying assumptions, again the risk of doath in commercial airline accidents is doubled if on the averoge each traveler doubles the number of miles he rides on commercial airlines or if twice the number of people ride on commercial airlines.

The ICRP, NCRP and FRC have indicated that in setting levels of permissible exposure to radiation it is a matter of balancing the benefits against the risks as indicated in Figure 1. This can be set more easily as a principle than it can be carried out in practice. In the first place, one can justifiably ask who or what group is competent and sufficiently authoritative and representative to balance the risks against the benefits in setting these standards. The NCRP, ICRP and FRC are made up of scientists and medical men who set the levels of permissible exposure to ionizing radiation in terms of what are considered to be acceptable . risks in comparison with other common risks in industry and society in general. They are awore of the great benefits from the use of ionizing sadiation but have not carried out a quantitative analysis listing all the benefits with their weighting factors or balanced them against all the properly woighted risks from such exposure. In any case, such an all wise group would have to obiain for all forms of man-made sources of radiation a summation of the ratio of the benefits to the risks to all members of the population who may be at risk and/or who may receive benefits. It would be extremely difficult to attach a quantitative unit of measurement to ench type of benefit and to each form of damage. Certainly in such a balancing act there would be many members of society who would receive great benefits with very few risks, while for others the reverse would be true. I doubt if it will ever be possible to carry out this balancing of benefits against the risks on a completely quantitative basis, but I believe those responsible for setting accesptable radiation exposure standards should strive constantly to do a better job in making these evaluations.

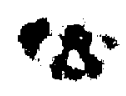




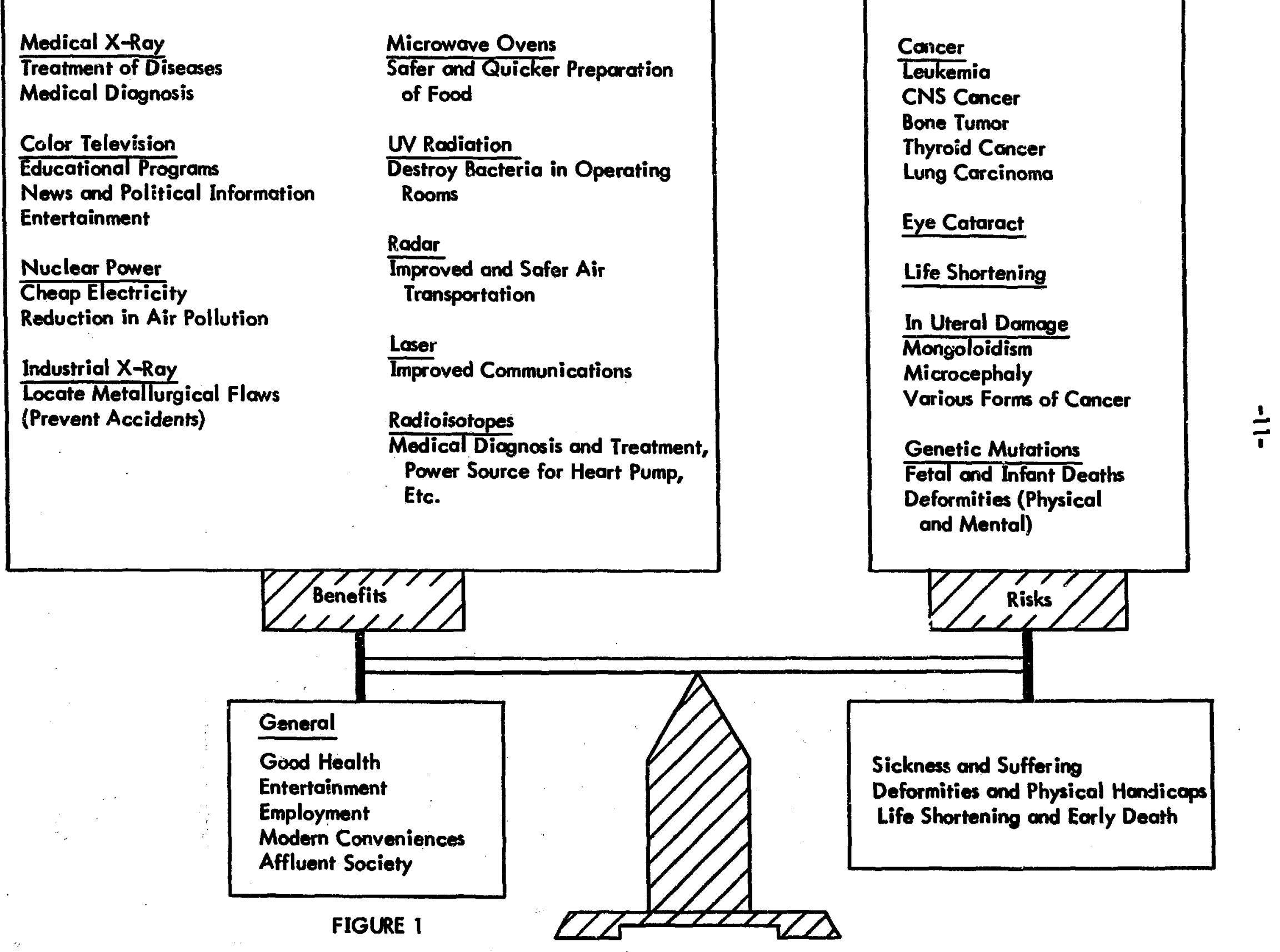


The aim of this papar is to show how dose limitations for members of the public should be applied in the control of redioactive effluents from nuclear power plants. It is importent to emphasize that in the final analysis the primary and most escuntial limitation must be on the abeorbed dose allowed to the critical body organs of individual members of the population and for the population as a whole. These absorbed dose limitations may be brought about by controlling a number of sacondary and tertiary parameters, but the measures taken are not adequate unless they take into proper account factors of dilution and reconcentration, meteorological condítions, population size and age distribution, ecological factors, food chains and in summary all important parameters which determine what happens between the point of release of the radioactive contamination at the reactor (and fuel reprocessing facilities) and the dose received by the individual in the population.

\section{Official U.S. Guides}

As indicated by the previous speaker, L. Rogers, the U.S. Atomic Energy Commission has published a Code of Federal Regulations referred to as Title 10, Parts 20 and 100 which refer specifically to permissible dose equivalents and measures which are required of reactor operations to assure the protection of occupational workers and members of the public from excessive exposure to ionizing radiation. Because of the detailed discussion of these regulations by Rogers, I will refer simply to a few tables and a graph which summarize these rules and regulations. Table 4 indicates the permissible dose equivalents in unrestricted areas. Table 5 indicates the surveillance requirements to assure the permissible dose equivalents in unrestricted areas are not exceeded. Table 6 summarizes precautionary measures which are specified by the AEC to minimize the risk of exceeding the AEC dose limits. Figure 2 indicates the meaning of the terms, exclusion area, low population zone and nearest population center. It is to be noted that the facilities are to be so designed and operated, and the exclusion area and low population zones are to be so defined that in the case of major accidental releases of radionuslides, persons living in the exclusion area will not receive more than 25 rem total body dose or 300 rem to the thyroid from any two hour exposure. 
Table 4

PERMISSIBLE DOSE EQUIVALENTS IN UNRESTRICTED AREAS (AEC Title 10, Part 20.105)

1. A person is permitted to receive no more than $500 \mathrm{mrem} / \mathrm{year}$.

2. Areas which could be continuously occupied must not deliver to a person more than $2 \mathrm{mrem} / \mathrm{hr}$.

3. Areas which could be continuously occupied must not deliver to a person more than $100 \mathrm{mrem} /$ week.

\section{Table 5}

SURVEILLANCE REQUIREMENTS TO ASSURE PERMISSIBLE DOSE

EQUIVALENTS IN UNRESTRICTED AREAS ARE NOT SXCEEDED

(Title 10, Part 20.106)

Concentrations of Effluents averaged over a year at boundary of restricted areo must not exceed values in AEC Table II of Title 10, Ch. I. These values in most cases are 1/10 of the values given by ICRP Publ.2 (1959)(7) and ICRP Publ. 6 (1964)(19) for continuous occupational exposure, $168 \mathrm{hrs} / \mathrm{wk}$. 
Table 6

PRECAUTIONARY MEASURES SPECIFIED BY THE AEC TO MINIMIZE RISK OF EXCEEDING AEC DOSE LIMITS

(Titlo 10, Parts $20 \& 100$ )

1. Licensee shall "minimize the radicactivity discharged in effluents to unrestricted oreas."

2. Licenses shall moke "such survoys as may be necessery for him to comply with the regulations."

3. 'Reactors will reflect through their design, construction and operation an extremely low probability of accidents that could result in releose of significant quantities of radicactive fission products." 


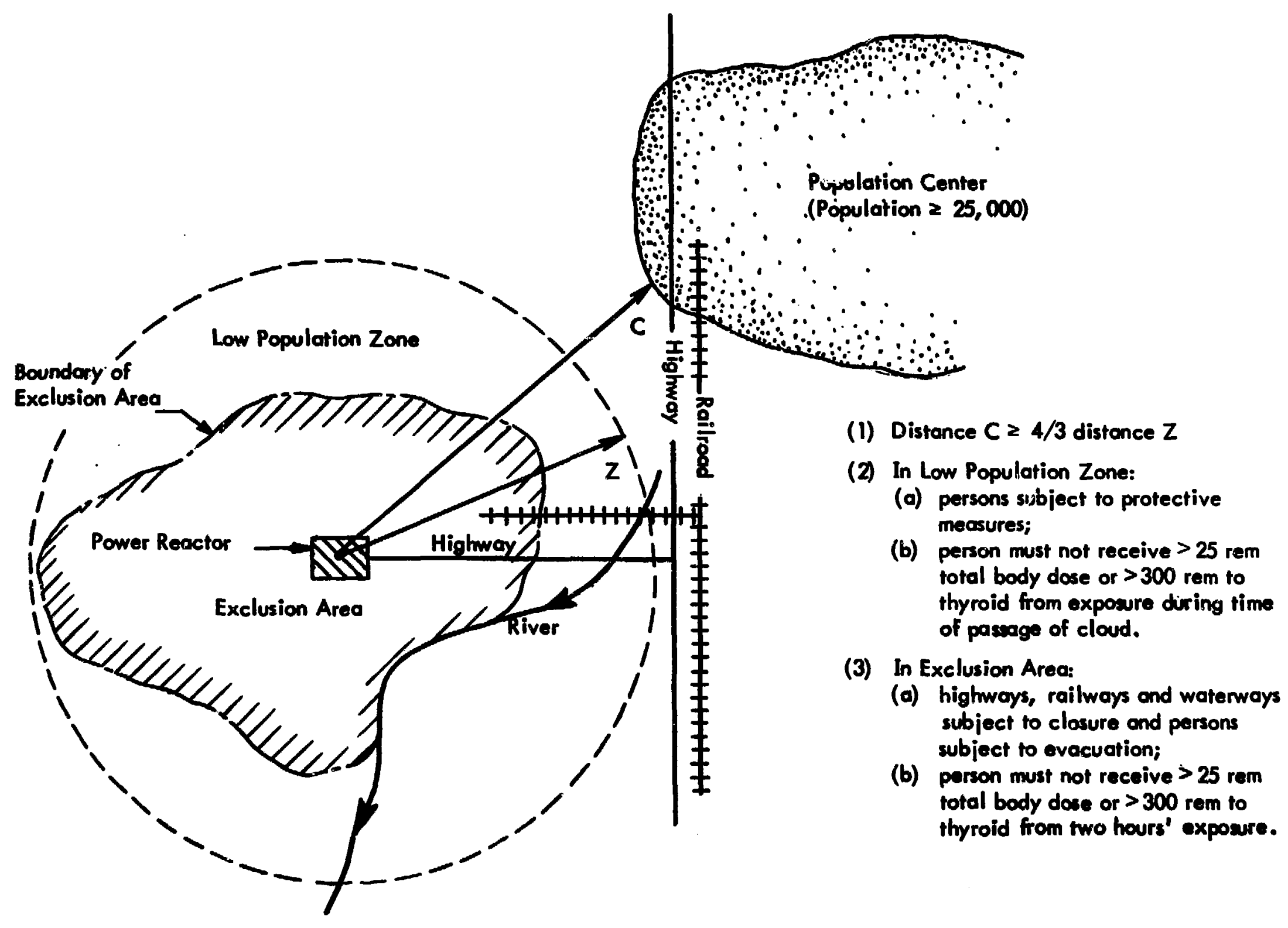

FIGURE 2 
Persons living in the low population zone must not receive mere than these same doses from. expciure dering the entire time of pasage of the radicactive. clowd. Papalations in both creas are abject to protective measures such as evacuation and the use of shelters in case of the passage of a radioactive cloud. There is perhaps not much which cen be done effectively to ascure protection of populations once the radioactive cloud paseses beyond the boundary of the low population zone. However, the mearest boundary of a population center with greater than 25,000 inhabitants must not be closer to the reactor than $4 / 3$ of the distance of the boundary of the low population zone from the reactor. This means that under the worst mateorologicol conditions some persons living in the nearest population center also might receive doses approximately equal to the limiting design values for persons living in the low population zone. Table 7 indieates, for example, the possible consequences of $10 \%$ of such average exposure to a population of $10^{6}$ persons during the time of a mojor reactor accident if one makes use of data provided by the ICRP. $(8)$

Before discussing the guidelines set by FRC and the recommendations of ICRP, it should be noted that in Title 10, Part 20, the AEC specifies that for routine discharge of radioactive materials from a nuclear power plant, it may be necessary to limit the quantities of released radicactive materials under certain circumstances into the air or water if it appecors the daily intake of radioactive material from air, water or food by suitable samples of the exposed population averaged over a period of a yoar would otherwise exceed the daily intake from continuous exposure to air or water containing $1 / 3$ the concentration of radioactive materials specified in AEC Table 2 of Title 10, Chapter 1. As indicated above, MPC values in this AEC table in most cases correspond to $10 \%$ of the MPC values given in ICRP Publications $2^{(7)}$ and $6^{(19)}$ for continuous exposure of the occupotional worker 168 hours per weok. These occupational MPC values in turn correspond to dose rates to the standard man after 50 years of occupational exposure as given in column 2 of Table 8. Thus, the does rates given in column 3 of Table 8 correspond approximately to the MPC values given in AEC Table 2 of Title 10, Chapter 1. One-third of these AEC MPC values would correspond approximately to the dow rates listed in column 4 
Table 7

CONSEQUENCES OF AN EXTREMELY RARE HYPOTHETICAL REACTOR DESIGN ACCIDENT

Type of

Radiation

Damage

1. Genetic

2. Fatal Neoplasms

Leukemia

Other Cancers

3. Thyroid Carcinoma

4. Life Shortening
Consequences of Exposure of $10^{6}$ Persons to $10 \%$ AEC

Design Exposures $\Delta$
$(1700)^{* *}$

40

40
$40 \mp$

$120^{7}$

$(400)$

Total

300 te 2300

${ }^{\Delta}$ This assumes $10^{6}$ persons are exposed to an average of $10 \%$ of the AEC Design Exposures (i.e., $10 \%$ of 25 rem to total body and $10 \%$ of 300 rem to thyroid). This assumes the linear hypothesis of ICRP(8) applies.

*This includes only the 1st generation genetic deaths and assumes the factor of $1 / 6$ applies.

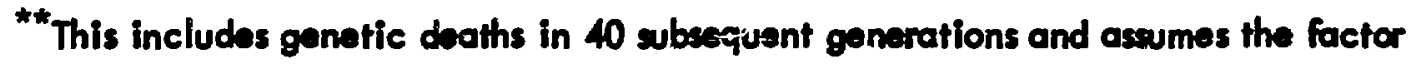
of $1 / 6$ applies.

F This includes only $10 \%$ of the thyroid carcinomas on aseumption $90 \%$ respond successfully to medical treatment.

FThis aseumes 70 years of life shortening corresponds to one death. 
Table 8

RECOMMENDED PERMISSIBLE DOSE RATE

Radiation

Protection

Guides Given

Values

Recommended

AEC Values

Limiting AEC by FRC $9,10,14$

Corresponding*

Values Undar for Exponure of

by ICRP for te AEC, Table II, Spocial

Population Groups

Body

Oec. Worker

Title 10, Ch. 1

Circumstances

During Norma! Peacetime

(rem/y)

( $\mathrm{ram} / \mathrm{y})$

(mram/y) (mrem/y)

Gonods, toral body \& red bons morrow

5

0.5

170

170

Skin, bone**

30

3

1000

$500^{\mp}$

Other internal organs

500

* These are estimated dose rates reached in the indicated body organ following intake of water or air concentrations of radionuclides given in AEC Title 10, Ch. 1, Table II by the typical adult individual continuously for $\mathbf{5 0}$ years.

** Thyroid was originally included with this group but is included now with "other internal crgans".

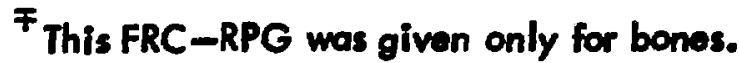


of Table 8. It is to be noted that the first value in this column 4 of Table 8 is the same as the average genetically significant dose limit sot for the total population by the ICRP and the FRC. Values of FRC radiation protection guides for exposures of population groups are given in column 5 of Table 8.

The average population dose in the U.S. at the present time from the nuclear energy industry is not known. We obtain this average population dose by dividing the total dose received by everyone in the U.S. (from all operations of the AEC contractors and from nuclear power plant operations) by the total population of the U.S. Our rough estimates indieate this dose is about $0.5 \%$ of the limiting AEC dose of $170 \mathrm{mrem} / \mathrm{y}$ or less than $1 \mathrm{mrem} / \mathrm{y}$. This includes both the dose received by the occupational workers and the environmental dose from these operations. It does not include the follout dose from atmospheric testing of nuclear weapons.

For illustration we have assumed in obtaining values in Table 9 that everyone in the U.S. received $0.5 \%$ of this $170 \mathrm{mrem} / \mathrm{y}$ (or $0.85 \mathrm{mrem} / \mathrm{y}$ ) and that the linear hypothesis of ICRP(8) applies. On such assumptions this low level continuous exposure would result in about 18 deaths/y or about 140 deaths introduced into the population per year as indicated in column 2 of Table 9. The genetic deaths would be limited to those among the live births but in the case of the 140 deaths/year most of these deaths would occur over the next 40 generations (1200 years). Also for comparison we have indicated the number of deaths per year in case the nuclear energy industry were to permit everyone in the U.S. to receive $0.5 \%$ of the present AEC dose limitations listed in column 4 of Table 8 . In this case, as indicated in column 3 of Table 9, there would be about 30 deaths/ $y$ and 150 deaths introduced into the population per year. The values in Tables 7 and 9 are rounded off in order not to imply unwarranted accuracy.

We believe the deaths per year listed in column 2 of Table 9 represent an upper limit to the radiation deaths per year from present operations of the nuclear energy industry in the U.S.

The realism of these estimates of risk and their acceptability depend on many factors beyond the realm of this discussion. We expect the assumptions made in Tables 7 and 9 lead to maximum estimates of radiation deaths and that at least 
Table 9

CONSEQUENCES OF HYPOTHETICAL EXPOSURE OF POPULATION-AT-LARGE TO ROUTINE RADIOACTIVE EFFLUENTS FROM REACTORS

Type of

Rodiation

Damere

1. Genetic

2. Fatal Neoplasms

Leukemia

Other Cancers

3. Thyroid Carcinoma

4. Life Shortening
Consequences of Expowre of Entire U.S.

Population to:

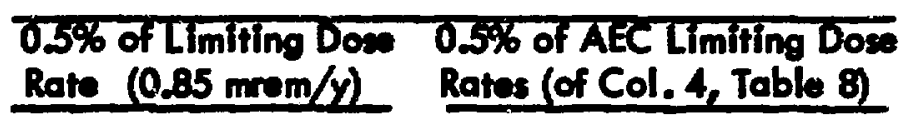

3*

$(120)^{* *}$

$3 * \quad(120) * *$

3

3

3

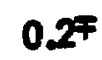

(2)

$9^{\mp 7}$

18 to 140

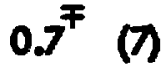

$14 * * *$

$9^{F F}$

30 to 150

*This includes only the lst generation genetic deaths and ascumes the factor of 1/6 applios.

** This includes gonetic doaths in $\mathbf{4 0}$ subsoquent gonerations and assumes the factor of $1 / 6$ applies.

*** This assumes $1 / 2$ of cancers originate in bone and $1 / 2$ in other tissue.

F This includes only $10 \%$ of thyroid carcinomas on assumption $90 \%$ rospond suecessfully to modical treatment.

FF This aseumes 70 years of life shortening corresponds to one death. 
for the next $\mathbf{3 0}$ years it is reasonable to expect the probability of a design accident such as that assumed in Table 7 or others of greater magnitude is less than $10^{-4}$ per year per reactor, i.e., less than one on the average per 50 years for an average of $\mathbf{2 0 0}$ operating power reactors. This would be equivelent in terms of lst generation deaths to the crash of one of the lorger aircraft every 50 years; hopefully the risk is less than 10-5. If, however, the risk of a desizn accident is as large as $10^{-4}$, the average risk over the next 50 years for an average of $\mathbf{2 0 0}$ nuclear power plants, in terms of average deaths per year, is less than one-half the risk from the routine operation of the nuclear energy industry, (i.e., 6 compared to 18 deaths/y or 46 compared to 140 deaths/y introduced into the population). Since any worthwhile enterprise of man is possible only by accepting certain inherent risks, the nuclear energy industry probably is not exception. The choice, therefore, seems to be between these relatively small hypothetical risks of the nuclear energy industry and the very real risks of power shortagas or a smag polluted environment and the associated respiratory diseases we might expect from fossil fueled power plants. If the population of the U.S. doubles by the year 2000 and the average dose to this population increases to $5 \%$ of the limiting AEC dose of $170 \mathrm{mrem} / y$ (i.e., increases to an average of $8.5 \mathrm{mrem} / y$ from the nuclear energy industry) the risk on the IERP(8) linear hypothesis for routine operation of reactors will have increased to 360 deaths/y and will be introducing 2800 deaths per year into future generations. If the risks of a design aceident remained about the same in the year 2000, the total risks in terms of death/ $y$ would be less thon the present risks of death in the U.S. from automobile accidents during a typical 3-day holiday woekend or the total deaths/y introduced into future generations would be less than those at present from automobile accidents in a single month. This contrast with automobile accidents justifies neither the automobile accident rate nor any relaxation in our vigilance in maintaining radiation risks of the nuclear energy industry as low as practicable. It emphasizes that health physicists must continue their efforts in maintaining the nuclear energy industry as one of the safest of all industries and must set a good example which will be emulated by the others. 
In 1958 the Federal Radiation Council (FRC) was authorized by Congress to "advise the President .... with respect to radiation matters directly or indirectly affecting health." As instructed by Congress, it "consults qualifiod scientists and experts in radiation matters, including the President of the National Acadamy of Sciences, the Chatrman of the NCRP, and qualified experts in the field of biology and medicine and health physics." The Secretary of Health, Education and Welfare is Chairman of this Council which consists of the Secretary of Health, Education and Welfare, Secretary of Labor, Secretary of Agriculture, Secretary of Commerce, Secretary of Defense, Chairman of the U.S. Atomic Energy Commission and the Special Assistant to the President for Science and Technology. The FRC publications have provided information on the amount of fallout from woapons tests and estimates on the possible consequences. They provide data, also, on some of the more importent radionucl ides that are of concern in the routine operation of nuclear power plants and of those of primary concern in case of reactor accidents. FRC Report No. $2^{(9)}$ provided three ranges to serve as guidance for surveillance and control of radioactive contamination. These ranges are related to the probability of exposed individuals reaching or exceeding the radiation protection guides, RPG's (column 5 of Table 8). The RPG's are defined as absorbed doses to individuals of the general population which warrant protective action and that should not be exceeded without careful consideration of the reasons for doing so. It was indicated that every effort should be made to encourage the maintenance of radiation doces as far below these guides as practicable, and these guides may be exceeded only after the Federal agency having jurisdiction over the matter has carefully considered the reason for doing so. Intakes in Range I would not under normal conditions be expected to result in any appreciable number of individuals in the population reaching a large fraction of the RPG. The only action required in this range is survelllance adequate to provide reasonable confirmation of calculations. Exposures in Range II are still not expected to exceed the RPG's but are high enough to require control 
measures, to observe trends and to be on the lookout for sudden rises in the activity which could lead to levels above the RPG unless certain countermeasures were taken. Exposures in Range III would be presumed to result in exposure exceeding the RPG if continued for a sufficient period of time. Transient rates of intake wishin this range could occur without the population exceeding the RPG if the annual average intake fell within Range II or lower. "Control actions would be designed to reduce the levels (from Range III) to Range II or lowar and to provide stability at lower lovels. These actions can be directed toward further restriction of the entry of radioactive materials into the environment or the control of radioactive materials after entry info the environment in order to limit intake by humans. Sharply rising trends in Range III would suggest strong and prompt action." Table 10 summorizes some of the values suggested for these ranges by the FRC for some of the more important fallout that might occur during the operation of nuclear reactors. In general, Range I is where operations would be expected, and Range II should not ordinarily be excoeded.

The FRC ${ }^{(11,12)}$ has provided three categories of exposure to the radionuclides which are considered to be of greatest concern in reference to fallout from nuclear operations, i.e., strontium-89, strongium-90; cesium-137 and iodine-131. Table 11 summarizes the values of protective action guides, PAG, for these three categories of exposure.

When the FRC was first established, some of us were very optimistic in the hope that this organization would make a serious attempt to balance the benefits against the risks in the use of ionizing radiation as illustrated in Figure 1. Unfortunately, this has not been the case. Some effort has been made by the FRC to review the risks discuseed in reports of ICRP, NCRP, United Nations Scientific Committee on the Effects of Atomic Radiation, the National Academy of Sciences, etc., but no effort has been applied toward matching these risks against the benefits as illustrated in Figure 1. Also, it was hoped that the FRC 
Table 10

VALUES SUGGESTED BY FRC FOR RANGES OF RADIONUCLIDES

\begin{tabular}{|c|c|c|c|}
\hline Range & $131_{1}(\mathrm{Cl} / \mathrm{d})$ & ${ }^{90} \mathrm{Sr}(\mathrm{pl} / \mathrm{d})$ & ${ }^{89} \mathrm{Sr}(\mathrm{PCl} / \mathrm{d})$ \\
\hline I & $0=10$ & $0-20$ & $0-200$ \\
\hline II & $10-100$ & $20-200$ & $200-2000$ \\
\hline III & $100-1000$ & $200-2000$ & $2000-20,000$ \\
\hline
\end{tabular}




\section{Table 11}

FRC PROTECTIVE ACTION GUIDE 11,12

\section{Category}

Applies to early transmission (mostly lst 100 days) by pasture-cow-milk-man pathway. The PAG for individuals is $10 \mathrm{rad}$ from $89 \mathrm{Sr},{ }^{90} \mathrm{Sr}$ and $737 \mathrm{C}_{3}$ in $1 \mathrm{st}$ yr to bone marrow or whole body and the total integrated dose must not exceed 15 rad (assumed that total dose of $89 \mathrm{Sr}_{\mathrm{r}}$ and $137 \mathrm{Cs}_{s}=1 \mathrm{st}$ yr dose or $10 \mathrm{rad}$ and total dose of $90 \mathrm{Sr}=5 \times$ lst yr dose $\left.\leq 15 \mathrm{rad}^{*}\right)$. In the case of $131_{I}$ the PAG is met if the average dose to the thyroid is $\leq 30 \mathrm{rad} / \mathrm{yr}$ to the individual or $\leq 10 \mathrm{rad} / \mathrm{yr}$ to a suitable sample of children of approximately 1 yr of age using milk from a reasonably homogeneous supply. It is assumed the PAG is met if the average projected dose to a suitable population sample $\leq 1 / 3$ above yalues for individuals (i.e. $10 \mathrm{rad} / \mathrm{yr}$ for 131 I, $3 \mathrm{rad} / \mathrm{yr}$ for ${ }^{89} \mathrm{Sr}$ and ${ }^{137} \mathrm{Cs}_{\text {, and } 1 \mathrm{rad} / \mathrm{yr} \text { for }}{ }^{90 \mathrm{Sr}}$ ).

Applies to dietary transmission during the lst yr by pathwoys other than Category I. The PAG for individuals is 5 rad from ${ }^{89} \mathrm{Sr}, 90 \mathrm{Sr}$ and $137 \mathrm{Cs}$ in lst $\mathrm{yr}$ to bone marrow or whole body. Assumed the PAG is met if average projected dose to a suitable population sample $\leq 2 \mathrm{rad}$ in lst $y r$.

Applies to longterm transmission of $90 \mathrm{Sr}$ through soil into plants. (May apply to ${ }^{137} \mathrm{Cs}$ for 1 to 2 years). Doses to bone marrow after lst yr may exceed 0.5 rad to individuals or 0.2 rad to a suitable population sample thus requiring appropriate evaluation and action.

* Although not stated specifically this implies the lat yr doce of $90 \mathrm{Sr}$ should not exceed $3 \mathrm{rad}$. 
would take the initiative in forreting our potentially dangerous radiation risks and take appropriate action before the development of serious consequences. In particular, we have in mind 1) the fallout of $\left.13\right|_{1}$ during the Nevada weopons tests leading to considerable population exposure in some cities of the U.S. in 1962 and 2) the exposure of uranium miners in the Colorado plateau area of the United States during the past decade. In spite of the 1961 statement of the FRC ${ }^{(9)}$ quoted above regarding actions that would be appropriate for Range III, when the "chips were down" and milk producers in the Salt Lake area were putting their cows on dry food and replenishing their supplies with imported milk because the milk levels were in Range III, the FRC recanted its position in a letter dated August 29, 1962, to the Joint Committee on Atomic Energy stating, "We want to point out that the guides are not intended to set a line at which protective action should be taken or indicate what kind of action should be taken." The situation regarding exposure of uranium miners illustrates the lack of action by the FRC until its hand was forced. As early as the year 1500, it was known that miners of certain ores (later discovered to contain uranium) died after a fow years of mining of a so-called miners' disease. It was many years later before it was recognized that these dooths were attributable to lung carcinoma resulting from exposure to the daughter products of radon given off from the uranium in these mines. Centurles later it was observed that bronchogenic, epithelial carcinomas appeared five to 20 years following exposure in the Schneoburg mines of Saxony and the Joachimsthal mines of Bohemia. In spire of these centuries of unhappy human experience from exposure of miners to urenium ores, the Federal Radiation Council did not take the initiative in calling attention to the many miners in the Colorado plateau who were engaged in mining operations where the lovels of exposure probably were equal to or greater than those that led to carly tragic experiences, and in any case they often were 10 to 100 times the lovels set by ICRP $(7,19)$. Even after the seriousness of this problem was brought into focus by the excellent work of Holadoy (13) and others with the Public Health Service, the FRC 
was slow in recognizing the problem and taking appropriate action. Finally, after long delays, the FRC recommended what amounted to I working level, $W$, which was three times the $0.3 \mathrm{WL}$ recommended by the Department of Labor. This $0.3 \mathrm{WL}$ was approximately equal to the value which ICRP $(7)$ had recommended $\left(3 \times 10^{-8} \mu \mathrm{c} / \mathrm{cc} \approx 0.3 \mathrm{WL}\right)$ in 1959. An even greater disappointment to some of us is the fact that the Federal Radiation Council has failed to take any action regarding what is by far the principal source of man-made exposure, namoly, excessive and unnecessary medical exposure. Many studies have indicated that diagnostic exposure can be reduced at least by a factor of 10 with very little effort. It is much higher in the United States than other advanced countries of the world and comprises on the average over $90 \%$ of all man-made exposure in the United States. It is encouraging that the FRC provided so much information in evaluating the problem associated with fallout from testing nuclear weapons which in the U.S. at the peak of fullout amounted to about $5 \mathrm{mrem} / \mathrm{y}$ but discouraging that it has done nothing to reduce the genetic medical diagnostic dose of $55 \mathrm{mrem} / \mathrm{yr}$. Of greater concern is the fact that although in $1960^{(14)}$ and $1962^{(9)}$ it first published the $170 \mathrm{mrem} / \mathrm{yr}$ as the average genetically significant dose and does to the whole body and bone marrow of the population, it made no attempt to indicate how this dose might be apportioned among various sources of ionizing radiation. In its corly publications, $(5,7)$ the ICRP suggested how this genetically significant dose might be apportioned, but in more recent publications ${ }^{(15)}$ it has dolegated this responsibility to the various countries by stating, "The Commission wishes to point out that it is important to inwure that no single type of population exposure take up a disproportionate share of the total. The way in which this is done will depend upon circumstances which may vary from country to country and will be determined by national, economic and social considerations." If the FRC had taken this matter soriously some years 090 and assigned some reasonable percent of the $170 \mathrm{mrem} / \mathrm{yr}$ to the nucleor power industry, it is very likely that somo of the heatod discusions, misunderstanding and controversy in the United States regarding the appropriatenexs of this expowure level for reactor siting might hove been avolded. We have no 
doubt that the AEC never intends to permit the nuclear power industry to use up all the total recommended population dose (averaged over the entire U.S. population) but it is clear that some persons are interpreting AEC Regulations, Title 10, Part 20 to this effect and the FRC could have assisted if it had apportioned the $170 \mathrm{mrem} / \mathrm{y}$ to various mon-made sources of exposure as recommended by ICRP.

The National Council on Radiation Protection and Measurements has had considerable influence in setting the official U.S. guides for radiation protection. Most of those who have prepared reports for the Federal Radiation Council' have been members of NCRP. The basis of the AEC values in Table 2 of Title 10, Chapter 1 , are escentially $10 \%$ of the occupational values given in the NCRP(16) Handbook 69. These NCRP values, in turn, are almost identical to those given in ICRP Publication 2 becouse many members of the NCRP committee which prepored the NCRP internal dose handbooks Nos. $52^{(17)}$ and $69^{(16)}$ were also members of a corresponding ICRP committee which prepared the ICRP internal dose handbook. Thus, the NCRP recommendations need not be discussed further at this time.

\section{ICRP Recommendations}

In view of the fact that the recent past chairman of ICRP has discussed the scientific basis for ICRP recommendations, there seems little need here to do more than summarize some of these recommendations. Table 8, column 3, lists the ICRP recommended dose limits for members of the public with the exception that the 0.5 is not specified as a limit for total body dose. In addition, the limit of $7.5 \mathrm{rem} / \mathrm{yr}$ is given for exposures to hands, forearms, feet and ankles. ${ }^{(15)}$ As indicated above, ICRP in its carlier publications recommended $5 \mathrm{rem} / 30 \mathrm{yr}$ (corresponding to an average of $170 \mathrm{mrem} / \mathrm{yr}$ ) as the genetically significant dose for a population. This continues to be a firm recommendation of ICRP, but, unlike its corlier publications, ICRP no longor attempts to subdivide this $170 \mathrm{mrem} / \mathrm{rr}$ among various sources of radiation exposure in a given population but rather encourages the vorious nationol bodies to perform this function taking into account the various sources of rediation and their importance to the population. The size of the population over which this genetically significant does might be 
averaged appropriately has never been defined clearly but is understood to be a population of similar social and ethnic backgrounds such that there is relatively unrestricted intermarriage among members of the population. For simplicity, it is often taken as the entire population of a country, but in some countries or communities it might be considered appropriate to take a particular ethnic group or social or religious segment of society over which to average this dose. ICRP considers that dose equivalent to a critical organ of the body is the basic or primary recommendation. In the case of internal dose, organ burdens would be a secondary recommendation, microcuries taken into the body per day a tertiary recommendation, and microcuries/ce a quaternary recommendation. The values in column 3 of Table $\mathbf{8}$ are planned exposures for individuals of the public and are referred to as dose limits. In the case of unplanned exposures from uncontrolled sources such as accidents, ICRP suggests various action levels be set by appropriate national authorities and that careful plans be made in order to offer guidance and appropriate action should certain emergencies arise. In most routine reactor operations, extensive monitoring of all elements in the environment including the population is not necessary. The ICRP ${ }^{(18)}$ emphasizes that pre-operational surveys should be mado, and from these and as a result of surveys continued after operations begin, it should be possible to select with considerable reliability the critical radionuclides, their critical pathways and the critical groups in the population. The critical radionuclides are those most likely to present problems in terms of ultimate exposure to man and/or detrimental effects on the environment. The critical pathways represent the various food chains including, for example, irrigation as one step by which these radionuclides may be transported and concentrated as they pass through the various stages of the ecosystem where they may produce damage directly or indirectly to man. The critical group in the population is that group of individuals relatively small in number and reasonably homogeneous that is considered to receive the largest dose to critical body organs and/or to receive the greatest domage from the radioactive contamination. Some of the facts which must be considered in selecting this critical group are location and age distribution, dietery habits, special occupational habits, 
type of dwelling and heating equipment, domestic habits, hobbies, efc. The critical group may for example be limited to males, females, pregnant women ar children of a given age. It may be individuals who eat certain types of food, religious groups that follow certain customs or persons with certain illnesses which affect their habits or metabolism. In any case, it is recognized that due to individual variability there will always be some spread in the dose received within such a critical group in spite of the fact that it is relatively homogeneous from practical considarations. The Commission ${ }^{(18)}$ allows half of the members of this critical group to exceed its dose limits in that the average dose of the critical group may be equal to but not greater than the dose limits given in column 3 of Table 8. It recognizes further that there will always be some members in a large population which hove peculiar habits which markedly enhonce radionuclide uptake, for example, an individual who may obtain a large fraction of his food from fish soup in which the bones as well as the flesh of the fish are consumed. In such cases the doses he recoives may be considerably greater than the recommended dose limits even though the ICRP's recommendations are complied with in that the average dose received by the critical group does not exceed these limits. This recommendation of ICRP is perhaps less restrictive than the AEC Regulations summarized in Table 4 in that the AEC states its dose limits are applicable to the individual and not the average dose recoived by a critical group.

The ICRP wisely points out that it is important that the design of the monitoring program should be reconsidered from time to time, and the initial design may have to be revised in terms of oversights, underestimates and now information. In our operations over mare than a quarter of a century at Oak Ridge National Laboratory, we have found it extremely important to carry on certain forms of environmental monitoring in order to assure outeolves that our early estimates and those revised from time to time regarding the dowe limits are sufficiently conservative. One can point to page after page of calculations which seem to show an operation is very safe, but this can never be as convincing as occasional grass samples, samples of fish and milk, studies of iodine uptake by the thyroids of cattle, sampling of various crustaceans 
in the rivers, occosional total body counts of a few inhabitants from the population and rewults of continuously monitoring air somples and river sompling devices downwind and downstream, respectively, from the reactor operations. The magnitude and extent of ach confirming evidence which is dasirable depends upon the circumstances, the magnitude of the operation, the size of the exposed population, the types of radionuclides that may be discharged, etc.

Interpretation and Application of Radiation Protection. Guides

As indicated above, the basis for limiting exposures of members of the public is the dowe to critical body organs and not derived criteria. In carly ICRP publications $(5,7)$, it was suggested that for planning purposes, one might as a first consideration use 1/10 of the MPC values for continuous occupational expowure as occeptable levels for the public, and because of environmental and human factors, an additional factor of $1 / 3$ might be applied in the case of somatic exposure and an additional factor of 1/10 applied for genetic expowre. In other words, the aggestion was that in planning the discherge from a reactor or radioisotope facility into the public domain one might as a first consideration set acceptable concentrations of radionuclides in air and water such that in the case of radionuclides for which gonads are the critical timue, the values were $1 / 100$ of the MPC values for continuous occupotional expowire. For all other radionuclides, the values might be set at 1/30 the MPC values for continuous occupational expoure. In retrospect perhaps this statement of ICRP had best not have been made becouse it has been misunderstood on so mony occasions. We believe what ICRP really intended to ey and whot it hos cloorly emphosized in all subsequent publications $(15,19)$ is that the dow to individual members of the population or the everoge dose to critical segments of the population should not exceed $10 \%$ of the values for the critical organs recommended by KCRP for the occupational worker (ICRP population dow limits listed under colven 3 of Toble 8). Ten percent of the MPC values for continuous expoure of ocappotional workers is not the same as $10 \%$ of the dose values listed in column 2 of Table for mony reasons, come of which are as follows: (1) the MrC values for consinuous exposure of the occupational worker are derived for. the stondend or typical man and may not apply for the child, infont, in uteral individual, or mambers in the 
population who have certain discases. For example, if the child drinks the same quentity of milk per day as the stendard man and has a thyroid 1/10 the size of an adult, the doce to the child's thyroid would be roughly 10 times that to the stendard man. The metabolic characteristics of many members of the population may differ wbstantially from thow of the standard man, and there may be groups in the population for which the cating and breathing habits, e.g., the water and air consumed per day, differ markedly from those of the standard man; (2) the MPC values for continuous exposure to the occupational worker are based on the dose rates reached in the critical body organs after $\mathbf{5 0}$ years of occupational exposure at a constant concentration of the rodionuclides in air or water. For exposure of the public to long-lived rodionuclides such as strontium-90 and plutonium-239, the calculation should be based on the does rate reached in the critical organs efter at least 70 years of expowre; (3) the MPC values for continuous exposure of the occupational worker apply speciffically to air and water. They can be applied to most foods since (with the exception of cartain foods such as butter) most foods are comprised principally of water. However, if, for exemple, a reactor operation were to rely sobly on mointaining the lovels of rodionuclides in the air and water at its boundories at $10 \%$ or les of the ICRP MPC values for contimuous secupational exponere (or the AEC values in Table 2 of Title 10, Chapter 1), no considieration would be given to the posibility of reconcentrotion foctors in the environment. It is wall known that when rodioiodine contained in air at the permissible concentration is woshed out by rains and attles in the gras of a dairy farm, it is theoretically powible that the concentration of iodine in the milk could be 1,000 or more fimes the permiselble concentrotion. Likewise, in river systems the bones of fith and cartain crustocsons may concentrate some of the radionuclides by factors of $10^{5}$ or more. Therefore, although the lovels of rodiocetivity in the air and water as they pase over the boundary of the reactor openation or exclusion area noy be cqual to or bes then the values given in AEC Table 2, Title 10, Choperer 1, or 10\% of KCRP's MPC volues for continuous exposire to the occupational workers, wech numbers alons do not provide asurence thet members of the population 
are adequately protected. In many instances, there may be dilution factors due to meteorological conditions it ine air or the mixing in river systems such that $10 \%$ of the ICRP MPC values for continuous exposure of the occupational worker is unnecessarily conservative. Futhermore, the exposure limits for members of the population (Table 8, column 3) are given on an annual basis and high dose rates are quite acceptable provided the integrated annual doses do not exceed the values given in Table 8, column 3. On the other hand, barring these dilution factors and in circumstances where reconcentration factors may lead to excessive annual doses of large populations or to critical groups of the populations such operations would be unacceptable. As explained previously, the ICRP has indicated that it usually is not necessory to carry out very extensive environmental monitoring at reactor and isotope facilities, but in preplanning and in subsequent studies to confirm the accuracy of calculations and the safety of an operation, it is essential that a number of various types of measurements be made to assure that the critical segment of the population has been properly identified and that no factors of reconcentration have been overlooked. Usually, the values given in column 3 of Table 8, should be regarded as upper limits of dose to individual members of the population, but ICRP would allow some slight deviation from this rule by applying these values to the average dose received by the critical segment of the population and not the maximum dose to any single individual. From a few limited studies by Snyder and Cook ${ }^{(20)}$, it is not anticipated that the maximum would exceed the average in this homcgeneous critical segment of the population by a factor greater than 3 approximately $5 \%$ of the time although it is recognized in exceptional cases the deviation would be much greater.

As explained above, one reason for departing from terminology such as maximum permissible, allowable, or tolerable dose was that it left the impression that such doses were quite acceptable and that no effort need be made to stay below these levels but that serious trouble would result if these doses were exceeded. It was. for this mason that the Federal Radiation Council used such terms as radiation profection guides. Throughout the publications of ICRP, it is emphasized repeatedly that maximum permissible doses, dowe limits, action levels, 
radiation protection guides, etc., are not to imply a serious risk to the individual should they be exceedad. On the other hand, every effort should be made to operafe as far below these levels as practicable (not as far below as possible). How for below these levels "is practicable" is a matter that must be given due consideration by the national authorities when authorizing radioisotope and nuclear facilities with reference to each particulor site. Due account must be given as discussed later to the use factor, reconcentration, population size and other sources of radiation exposure to the population. With sufficient expendifure, the concentration of radioactive effluents from a power plant could always be maintained very low and even lower than ambient levels in the environment. Although the levels of radioactivity added to the effluents by a power plant could be kept at such a level that the dose to the critical sogment of the population would not exceed, for example, 1/1,000 of the dose levels summarized under colum 5 of Table 8, this might not be necessary or worth the effort unless it could be done at little or no cost to the operation. If measures to keep the population dose far below dose limits set in Table 8 were very expensive, the goals probably thould be set with less stringent standards. In any case, the purpose of health physics protection would be defeated if the required operating levels for a nuclear power plant were set so low that a fossil fuel plant was constructed at a site and especially if in exchange the population doses from radioactive effluents from the plant were higher than those from a nuclear plant which, in addition, would not discharge chemical contaminants into the environment.

\section{Criteria for the Control of Routine Discharges of Radioactive}

\section{Effluents from Nuclear Energy Establishments}

In the remainder of this paper, we shall consider routine discharges from nuclear energy establishments of low activity effluents to the atmosphere or to some neorby river. Problems associated with release of high activity debris following a serious reactor accident are special situations outside the scope of this paper, requiring considerations primarily related to reactor design, engineered 
safeguards and reactor siting. We shall concem ourselves here only with the development of criteria for the control of routine discharges from normally operating muclear energy installations (6.0., research reactors, power reactors, fuel reprocessing plants, etc.). While our discuscion doals with this motter as we would face it in the U.S., we hope thet the principles involved apply in any nuclear country.

Criterion as usad here moans the dow allocotions and corresponding secondary and fertiary standards that are selected and applied in this context to keep the actual or potential doses to man from this single type of population exposure, ise, the exposures of members of the public to routine rediocetive discharges from muclear estatlishments, as low as procticable.

In presenting this, we recognize a number of obetacles which must be overcome before these sugestions are likely to be accepied by todoy's public. There is a credibility gop concerning basic rodiation protection standards in the U.S. created by the claims of some that current permiselble dow limits of the Federal Radiation Council are too high and that population expenures up to these levels will produce daths numbering in the tens of thousands. There is another credibility gop concerning nuclear reactors themselves. Nuclacer peviver reactors are being criticized in the U.S. roday on grounds that their effluenis are hazardous to the public or that they relcoise dengerous amounts of radioactivity. Another obstacle is today's concern for environmental quality. This concern for environmental values co-exists with an unprecadented publie demand for participation in nearly all focets of the docision-making procen. Thus, any erituria for the control of all wate effluents, not just reactor effluents, must be prudent and presented in longuege the public cen undersiond so that the public con make the choice in its owm solf interest.

Factors for Considaration in Selecting Criburio for the Control of Rodlonctive Discharges to the Emvironmont

Our study of the radiological problems with routine discherges of low activity affluents from nuclear establishments loads us to cnumarate swvel facters which we believe should be considered by notional authorities in wbeting dow 
allocations and cormepponding secondary and tertiony standards to be applied in this context. Let wo be reminded again that we one coneerned here only with the radiological effects of redicoctive moterials in effluents dischorged to the environment and not with other condiderotions as, for exomple, thermal offects in the environment.

(1) The main obpetive of these criteria should be to protect man. This is not to wy that ecological effects ane unimportant, but rother that routine discherges from normally operating mucleor plents have not been shown to be of ecological sionificance. The pouibility of ecological effects must not be ignored, however, now or in the future.

(4) For the reason given in (1) ebove, the basis for control thould be the actual or potential dow to mon, ho being the rediation recepter of primary concarn. The KCRP acoects that the bacis for limiting rediotion expoures of mambers of the public should be "whe dowe to the verious body ongons (of men) and not the darived crilurila by which the dow is controlled." (2I)

(3) The ectual or potential rediotion dow to man from exposure to routine discharges of low activity effluents frow nucleor plents should not telke up a disproportionate shere of the cectual or potsontial radiation dows from all sources, excluding notural bockground and madical scurces. This follows from other quidence offered by the ICRP: "-n-we-dit is importent to envere that no single type of population exponure vekes up a disproportionate shere of the total.".(22)

(4) The ICRP recommendes that the genetic dow of 5 rems in 30 yeers from all wources, axcheting noturel beckeround and madical sources, be opportioned for plonning purpows to allow for dovelopenent of nuclear enerey procoroms. (23) Undarscoring the importance afteched to this problem, the ICRP, in one of its corly reports (24), wavented on Illustrative apportionment. This coms to be regorded as hoving more significence then the ICRP iniendad, so it batses report moraly ammerizes the contributions to ganetic dos from verious sources

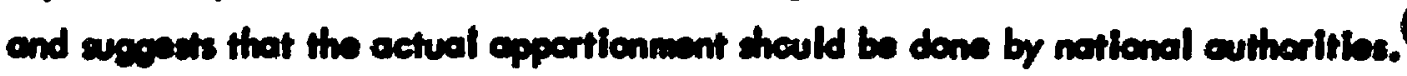
As statud before, we beliove the Fedaral Rodiation Council thould get on with this rak now so thot on appropriots dow allocation and the comseponding cribrib can be appliod in this contoxt. Inetienially, beceun of the comparatively high 
mean genetic dose to the U.S. population of $55 \mathrm{mrems} /$ year from medical expoures, we believe, contrary to the ICRP's point of view, that this should be considered in the FRC's apportionment of genetic dose for the U.S.

(5) With the possible exception of the critarion related to genetic dowe in (4) above, there is reason to believe that dose allocations to organs other than gonads applied in the control of radioactive dischorges to the environment could vary from place to place, just as other environmental qualities vary from one area to another. Such situations, however, are not likely unles there is evidence that a given population group's exposure history is, and will continue to be significantly higher than the norm from whatever radiation source, natural or mon-mode.

(6) The dose allocations opplied in controlling radioactive offluents should be revised from time to time as knowledge is obtained on the population dows from low activity effluents. The present U.S. criteria (26), for example, ore exentially ten years old; we believe it's time they were recost. The 10 CFR 20 Rules and Regulations are subject to misinterpretation and, in soms mecoure, ore responsible for the current controversy concerning the hazend of reactor effluents.

(7) The present plans to reduce and control country-wide air pollution in the U.S., where the Federal government and the States cooperate in eatablithing ambient air quality standards and air quality control regions, could be extended to include the control of rodicactive pollutants as well, permitting use of the copabilities of existing pollution control agencies ot the federal, state and local levels to imploment on effective radiation monitoring prosram in the geographical areas where it is needed now and in other areas of the country as the need arises. Wo beliove the radiation monitoring program should be extablished in officially designated natural air basins and watertheds in which the nuclear ectablishments are locasd. Unlike the air quality control regions boing designated presently, where political subdivisions within given oreas oppeor to be an importent considaration in setting the boundarles of control arsas, we beliove the control areas hould bo small, natural air basins and watersheds (whose boundaries need not necenarily coincide) where elimate, meteorology, 
hydroloay and topography form a more or les hemogeneovs environmental unit. These control areas should not be so laree in areal extent that the redionuelide identities and concentrations in environmental media attributable to the nuelear plont(6) in question are "lost" lono before the air or water has reached the bounderios of tise besin. Other considerations in sotting the boundaries of control areas would be: lond use, the presence of other polluters, the puriadiction of existing pollution control cenencies, population density and distribution, and perhape others.

(8) The control area in (7) above should be monitared in accordence with the principles of environmental monitoring defined by the ICRP. (18) The monitoring program would then "hrace" the critical radionuclides through critical expowure pathways to the critical population group. The aim is to obtain only that information on the above "critical" factors noeded to obtain a valid estimase of annual population doses or asaurance that annual population dows do not excesd an upper limit of dow. Control area monitoring should supploment that required of the plant operator in ( 9 ) below.

(9) Ench nuclear plant operator hould be required to monitor his operations weh that the emisions of radionuclides discharged in significant amounts from the plant site are known and reported to the pollution control agency in the air basin or watershed involved. Here, too, the environmental monitoring principles described in ICRP Publication $7^{(18)}$ should be appliad.

(10) The restrictions placed on radicactive discharges from a given nucleor plant by the pollution control agency in the air basin or watersted involved, aimed at keoping the population dows within a selected radiation dose allocotion, should be based on actual plant performance, and not on dasign specifications or predictions.

(11) A technical bosis should be established in each air basin or waterehed (control area) which will sarve to limit rodioactive dischorges from nuelear plants currently in operation and which will afford a logical basis for limiting additional discherges to the air basin or watershed from nuelear plants of the future. 
Establichment of Criteria for Radioactive Discharges to the Environment. It is not within our purview to sugesst what quotas or dose allocations of the currently parmissible dos limits should be assigned to this type of population expoxire, in., the exposures to members of the public to radioactive contamination in the environment due to discharges of radicactive effluents from normally operating nuclear plants. This should be done by an appropriate national authority as, for example, the Fedaral Radiation Council in the U.S. In establishing a country's dose allocations for this type of population exposure, the national agency thould rake account of the following: (1) the country's current inventary of radiation and redioactive centamination sources that couse significant population exposures (in numbars of people exposed and/or in actual or potential doses received) and estimated population doses resulting therefrom; (2) the country's plans for expending nuclear energy programs and increasing the number and/or size of nuclear plants (e.0., power reactor plants and reactor fuel reprocessing plants); (3) the country's population exposures from other significant radiation or radioactive contamination sources (6.0., population groups living downwind or downstream from existing nuclear plants, population groups living in areas where world-wide fallout levels are above average or where unusual concentrations of fallout radionuclides occur, population groups experiencing above average radiation doses from medical and dental $X$-ray exposures, etc.) and (4) other social and economic considerations, attempting some sort of balanefitivg of benefits and risks. When this is done, fit might be expected that some appropriate fraction of each pormissible doce limit for each critical orgon will be allocated to this particular type of population exposure. For purposes of simplifying the application of these dose allocations in practice, some practical limits ( $.0 .$, permissible concentrations of radionuclides in air and water, permissible daily intakes, or permissible body or organ burdens of radionuclided) can be derived from these dose allocations and applied as in usual health physics practica. We would prefer that it become standard health physics practice to carry the assossment through to an estimate of orgen dose or at least, thort of that, to an estimate of radionuclide intake. These values, then, are the "criteria" refarred to in the context of limiting population exposures from radicactive discharges to the envircirment. 
Implementing and Applying Radiation Dose Allocations to Radioactive Effluents.

We look upon the potential benefits and ridks of mucleor energy progroms as baing worthy an entire nation's concern. We, therefore, believe that an importont degree of planning and regulating of the nucleor industry should rest with cosencies of the national government, such as, for example in the U.S., the Faderal Rediation Council, the Atomic Energy Commission, the Public Health Service. Perhape other agencies in the U.S. govemment also should bo involved, e..., the President's Council on Environmental Quality, the Federol Power Commission, and the proposed Emironmental Protection Aoency. We believe the leadership and coordination meaded should be providad by the Environmental Quality Council. The moin objective of auch planning and regulating at the foderal level should seck to place the mucleor plants in the safest and most effective locations. Once this is accomplished, most, if not all, of the radiological sofoty problems are minimized and rather casily managed. Another important objective of activities both at the federal and state levels should be a forthright program of public education about nuclear energy, including its benefits and its risks.

To apply the dose allocations, and the corresponding secondary and tertiory sandards, in this context will require a carefully desioned orea monitbring program. The aim is to establish a reasonable program that provides the information needed to evaluate the impact of low activity discharges from nuclear plants to an air basin or watershed in terms of population radiation doses. The low activity levels and the consequent low population doses to be expected will require on accurate monitoring system that focuses sharply on (1) the physical and biogeochemical behavior of radionuclides released to the basin in significant amounts and (2) the population factors which affect the actual or potential rediation dose to the critical organs of concern.

Designation of Control Areas. Federal agencies, such as the Environmental Sciences Service Agency (ESSA) and the U.S. Geological Survey (USGS) in the U.S., thould be given responsibilities to define the air basins and waterhods which will serve as control areas for rodicactive discharges to the atmosphere and to rivers, respectively. These environmental units will sugoest themselves, 
to begin with, because of the common climate, meteorology and fopography in air basins, and the common climate, topography and hydrology in the watersheds. The boundaries of the air basins and watersheds need not coincide. Further definition of the boundaries of a given air basin or watershed may be agoested by other factors held to be in common such as land us, water us, industry, agriculture, recreation, etc. The boundaries of these control aneas, in our opinion, should not be set by state or local political subdivizion, although that may be the only practical solution in some circumstances. Once the boundaries of the control areas hove been tentatively establimed the pollution control agencios at the fedaral, state and local lovels should conduct public heorings in the geographic areas involved to allow citizens or their represenfatives a chance to be heard and to understand all of the implications involved in the designation. This is a very important first step, and the success of succeeding steps in the procedure hinges lorgoly on the effectiveness and public understanding and acceptance of these designated control areas.

Establishing Minimal Areo Monitoring Requirements. The foderal coencies responsible for establishing the boundarles of the control area, presumably on the basis of good information coneerning the meteorological and hydrological characteristics of the air basin or watershed involved, together with the faderal, state and local pollution control agencies concarned, should reach an agreement on the restrictions to be applied and the minimal monitoring program that will be required. If the state or local authorities involved wish to apply tighter restrictions on nuelear plont discherges, and therefore to implement a more elaborate monitoring program, than those required to maet federal requirements, and if such restrictions are compatible with those of the noighboring control areas, they should be permitted to do so.

Monitoring the Control Area. Some pollution control agency having responsibilities in the control area (6.g., state or local public health departments, state or regional air and water pollution control boards, and environmental protection agencies) should aswume responsibility for implementing the area monitoring program. The meteorological and hydrological characteristics of the control area and monitoring information 
should be built into a disparsion modal and computer program that will permit. estimates of intakes or dose estimates to be made relative to exposure of individuals and/or critical groups. The results of monitoring, which will be in terms of annual average doses, should be made public as frequently as desired, or at least four times cach yeor. These does estimates sinould be reported in terms understandable to the public.

Applying the Criterio. Given an effective orea monitoring system based on (1) knowledoe of the radicactivity being released from the nucleor site(s); (2) modals simulating meteorological and hydrological charocteristics of the bosin which tend to disperse the activity released from the nuclear site(s); (3) understending of the exposure pothways leading to man; and (4) dosimetry techniques for estimating and/or measuring rodiation doses received by mon, it is then possible to assess the population exposure situation in the control orea at any time, comporing the actual or potential dose (s) to the critical group(s) with the dose allocations extablistred for that area.

As the first nuelear plant in a control area "comes on stream", and its performence is demonstrated, the pollution control agency in the control area may chooes to allow routine diechorges which result in a population dose or dose extimate up to the full level of the dose allocation; however, as succeeding nuclear plants are built and their dischorges are added to the bosin "load", then proportionote decreases in the respective discherges of each plant will be required.

It should be understood that the stope outlined abowe are token only where and as the need orises. For example, the designotion of control areas should begin only with the geographical areas in which power reactors or nuclear installations are currently operating or soon to be built. From theri on, the designations and implementations con proceed into other areas, as new plants ore built and the nuclear industry expands. 
It is pocible also that the dischanges of redioective effilinents frem some plonts, offer thair operations how been demondwesed and thels

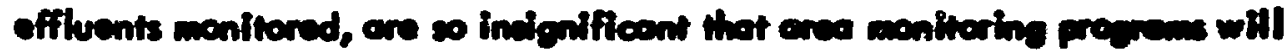
not be required, ise. the plent opereter's monitering reperts will be sufficient to asure the public thot the plent's discherges coes not haserdons. 


\section{REFERECES}

(1) MARTIN, JAMES E., HARWARD, EARNEST D. , OAKLEY, DONMLD T., Compertion of rodioestivity from foesl fubl and nucleor power plonts, Public Healith Sarvice, Departiment of Health, Educotion and Walfore November 196\%.

(2) Consideretions offecting steam power plent site selection," a report sponesed by the Enerey Policy Stoff, Office of Science and Technology, and atumitted as part of Heorings before the Subcommittece on Air and Wheres Pollution on S.7 and S.54, Serial 91-2, Part 4, p. 1109.

(5) MACMAHON, ERLN, X-roy exposere and molignoncy, JAMM, Vol. 183, p. 721 (1963).

(9) DUSSEL, W. L., Shudies in mommalion radiation genotics, Nuchonics, Vol. 23, No. I (bonwery 1965).

(G) Internotional Commision on Radiological Protection, Reconmendations of the twremotional Commizion on Rediological Protection, ICRP Publ. 1, pores.30-31, Pergemen Prex, London (195\%).

(6) Somotis radietion dow for the general populotion: Ad Hoc Committes Repert of the Notionsl Committee on Rediotion Protsetion and Moosurements, My 6, 1959, Science 131, 482 (1980).

(7) Iniernotional Commision on Rodiological Protsetion, Recommendations of the Inturnational Commission on Rodiological Protection, ICRP Publ. 2, Progmen Frex, London (19S9).

(i) Invernetional Commixsion on Rodiological Provection, Racommendotions of the Internetional Commission on Radiological Protection, ICRP Publ. 8, Pergomon frest, London (1966).

(9) Fedaral Rediotion Counsil, Beckground Moterial for the Developmgnt of Rediotion Prowetion Stonderd, FRC Publ. 2 (Sopt. 1961).

(10) Federol Radiotion Council, Health Implicotions of Fallout from Nucleor Weopons Testing Through 1961, FRC Publ. 3 (Moy 1962).

(11) Foderal Rodiation Council, Background Moterial for the Dovelopment of Rediotion Protsetion Stondords, FRC Publ. 5 (July 1964).

(12) Fodaral Rodiation Council, Bockground Moterial for the Development of Recilation Protection Standards, Protective Aetion Guldes for Strontium-89, Strontium-90, and Ceshum-137, FRC Publ. 7 (Moy 1965). 
(13) HOLADAY, D. A., Radiation hazards in uranium mines, Radiological Health Data 3, 135 (1967).

(14) Federal Rodiation Council, Bockground Material for the Development of Radiation Protection Standards, FRC Publ. 1 (May 13, 1960).

(15) International Commission on Rodiological Protection, Recommendations of the International Commission on Radiological Protection, ICRP Publ. 9, Pergomon Press, London (1\%6).

(16) Maximum Permissible Body Burdens and Maximum Permissible Coneentrations of Rodionuelides in Air and in Water for Oceupational Exponure, Recommendations of the National Committee on Radiation Protection, National Bureou of Standards Handbook 69 (1959).

(17) Maximum Permissible Amounts of Rodioisotopes in the Human Body and Maximum Permissible Concentrations in Air and Water, Recommendotions of the National Committee on Rodiation Protection, National Burear of Standards Handbook 52 (1953).

(18) International Commission on Radiological Protection, Recommendations of the International Commission on Radiological Protection, ICRP Pub!. 7, Pergomon Press, London (1965).

(19) International Commission on Rediological Protection, Recommendations of the International Commission on Radiological Protection, ICRP Publ. 6, Peroomon Pross, London (1964).

(20) SNYDER, W. S., COOK, M. J., Voriability of relative organ concentration of trace elements in human tissue, Health Physics, Vol. 9, pp. 57-62 (1963).

(21) International Commission on Radislogical Protection, Recemmendations of the International Commission on Radiological Protection, ICRP Publ.9, p. 13, para. 74, Pergamon Press, London (1966).

(22) International Commission on Radiological Protection, Recommendations of the Internotional Commission on Radiological Protection, ICRP Publ. 9, p. 15, pare. 87, Pergomon Press, London (1966).

(23) International Commission on Radiological Protection, Recommendations of the International Commission on Radiological Protection, ICRP Publ. 6, p. 32, para. 65, Pergamon Press, Londen (1964).

(24) International Commission on Radiological Protection, Recommendations of the International Commission on Radiological Protection, ICRP Publ. 6, p. 31-32, para. 65, Pergamon Press, London (1964). 
(25) International Commission on Radiological Protactlon, Recommendations of the International Commission on Radiological Protection, ICRP Publ. 9, p. 16, paras. 88 through 94, Pergamon Prose, London (1966).

(26) U. S. Atomic Enorgy Commision Rulos and Regulations, Titlo 10, Parts 20 and 100, Cods of Foderal Register.

(27) MORGAN, K. Z., Adequacy of present standords of radiation expousre, Teatimony before the Subcommittee on Air \& Water Pollution of the Senate Committie on Public Works, Washington, D. C., 1970.

(28) MORGAN, K. Z., TURNER, J. E., Prinelples of Rodiation Protection, John Wiley \& Sons, Ine., Now York, London, Sydnoy (1967). 